\title{
International Evidence on the Quality of Analysts' Cash Flow Forecasts
}

\author{
Changjiang Wang \\ Lindner College of Business \\ University of Cincinnati \\ Wang2cj@ucmail.uc.edu \\ 2624 Clifton Avenue \\ Cincinnati, OH 45221 \\ Minna $\mathrm{Yu}$ \\ Leon Hess Business School \\ Monmouth University \\ miyu@monmouth.edu \\ 400 Cedar Ave \\ West Long Branch, NJ 07764
}

\begin{abstract}
Using a large international sample from 1995 to 2018, we find that earnings forecasts accompanied with cash flow forecasts are more accurate than those not accompanied with cash flow forecasts, suggesting that Call et al. (2009)'s findings in U.S. apply to other countries. We then explore country characteristics that moderate the effect of cash flow forecast provisions on earnings forecast accuracy. We find that the positive association between cash flow forecast provisions and earnings forecast accuracy is more pronounced for firms domiciled in countries with a low disclosure level. We also expect and find that the positive association between cash flow forecast provisions and earnings forecast accuracy is stronger before mandatory IFRS adoption. Taken together, our results suggest that the advantage of forecasting cash flow, in terms of improving analysts' own earnings forecasts, is mitigated in countries with higher disclosure level and after mandatory adoption of IFRS.
\end{abstract}




\section{International Evidence on the Quality of Analysts' Cash Flow Forecasts}

\section{Introduction}

In this paper, we examine whether earnings forecasts accompanied with cash flow forecasts are more accurate than those not accompanied with cash flow forecasts in an international setting. Financial analysts are the capital market intermediaries who interpret and disseminate corporate information to other capital market participants. The extant literature has provided U.S. evidence on the usefulness of analysts' cash flow forecasts (e.g., Call et al. 2009 and 2013, Lehavy 2009, Givoly et al. 2009 and 2013, Hashim and Strong 2018). However, we have little evidence on the relevance of these forecasts in an international setting. Examining whether the provisions of analysts' cash flow forecasts give rise to more accurate earnings forecasts in an international setting is interesting for several reasons. First, cash flow forecast issuance is more pervasive in countries other than U.S. ${ }^{1}$ Therefore, it is interesting to investigate the outcomes of those cash flow forecast provisions. Second, investor protection has been documented as an important factor in the usefulness of cash flow forecast issuances (DeFond and Hung 2007). Therefore, the international setting allows us to explore country variation in investor protection and assess whether the usefulness of cash flow forecasts varies across countries. Third, DeFond and Hung (2003) propose a demand theory and document that investors demand more cash flow forecasts when firm's earnings quality is low. Subsequent studies (e.g. Bilinski 2004, Ertimur and Stubben 2005) have challenged the demand theory. An

\footnotetext{
${ }^{1}$ During 1993-2005, of the firms that analysts provide earnings forecasts, $26.2 \%$ have at least one cash flow forecasts (Givoly et al. 2009). From 1993-2008, 29.9\% of firms have at least one analyst cash flow forecast. $14.8 \%$ of their sample analysts provide both earnings forecasts and cash flow forecasts (Call et al. 2013 Table 1). In contrast, in their global sample of 36 countries during 1994-2002, DeFond and Hung (2007) report 45\% of firms have at least one cash flow forecast available during the year that analysts' earnings forecasts are provided. Hashim and Strong (2018) report that, during 2000-2010, analysts provide cash flow forecasts on the same day for $10 \%$ of their earnings forecasts in U.S. In our sample, on average, $32.01 \%$ of earnings forecasts are supplemented with cash flow forecasts worldwide.
} 
international setting can shed light on this debate by exploring the mandate adoption of International Financial Reporting Standards (IFRS thereafter), which is an exogenous shock to accounting standards and earnings quality, on the usefulness of analysts' cash flow forecasts. Given that IFRS has increased the quantity and quality of the accounting information environment (e.g., Barth et al. 2008, Landsman et al. 2012, Lang and Stice-Lawrence 2015, Li and Yang 2015), we expect that it reduces the benefit of analysts' cash flow forecasting and disseminations.

Using a large international sample over 1995-2018, we document that the issuance of cash flow forecasts is positively associated with earnings forecast accuracy, suggesting that the findings in Call et al. (2009) generalize to an international setting. Cross-sectional analyses indicate that the association between cash flow forecast provisions and earnings forecast accuracy is stronger for those earnings forecasts issued for firms domiciled in countries with lower disclosure level. In addition, the effect of cash flow provisions on earnings forecast accuracy is mitigated after mandatory IFRS adoption.

Our paper contributes to the literature in several ways. First, although there is extensive research on the quality and usefulness of cash flow forecasts in U.S. (e.g., Call et al. 2009 and 2013, Lehavy 2009, Givoly et al. 2009 and 2013, Hashim and Strong 2018), we know little about the usefulness and the quality of analysts' cash flow forecasts in other countries. Our paper fills in this gap by documenting that analysts improve their own earnings forecasting performance when they issue cash flow forecasts in an international setting.

Second, our paper contributes to the research on how the improvement of accounting standard (i.e., IFRS) affects financial analysts. Byard et al. (2011) document that mandatory IFRS adoption improves financial analysts' earnings forecasting performance. Demmer et al. 
(2019) document that one of the mechanisms that IFRS adoption improves financial analysts' earnings forecast performance is through its improvement of financial statement fundamentalbased forecast accuracy. Our findings extend this line of research and reveal that analysts' own cash flow forecasts are not as useful in the presence of more and higher quality firm-specific information induced by IFRS.

Third, our paper sheds light on the debate about demand and supply side of cash flow forecasts. Though we don't directly test the demand and supply theory of cash flow forecasts, our findings that analysts' cash flow forecasts become less useful to analyst's earnings forecast after the IFRS adoption provide indirect supportive evidence on the demand theory of cash flow forecasts.

The remainder of this paper is organized as follows: Section 2 reviews the relevant literature and Section 3 develops hypotheses. Section 4 describes the research design and Section 5 describes our data and sample. Section 6 presents the empirical results. Section 7 presents additional analyses, and the final section summarizes and concludes the study.

\section{Literature review of cash flow forecasts}

DeFond and Hung (2003) is the first study to examine analysts' cash flow forecasts. They find that, in U.S., the provisions of cash flow forecasts are mainly due to analysts intending to meet the demand of investors for firms that have poor earnings quality. Use an international sample, DeFond and Hung (2007) find that analysts are more likely to provide cash flow forecasts in countries where investor protection is weak and disclosure level is low, consistent with analysts reacting to investors' demand for earnings information to issue cash flow forecasts. Contrary to DeFond and Hung (2003) and (2007), who use demand theory to explain the provisions of cash flow forecasts, Bilinski (2004) develops a supply theory to explain the 
provisions of cash flow forecasts. He argues that, when earnings quality is low, analysts are not able to provide accurate forecasts of accruals, and therefore accurate forecasts of cash flow, which makes them reluctant to report cash flow forecasts. In support of his theory, he shows that analysts are not willing to disseminate their cash flow forecasts for firms who low earnings quality.

Ertimur and Stubben (2005) acknowledge both demand theory and supply theory. They find that both investors' demand and analysts' willingness to provide cash flow forecasts explain the issuance of cash flow forecasts. Specifically, analysts associated with brokerages of small size have less incentives to provide cash flow forecasts, consistent with the supply theory. $\mathrm{He}$ and $\mathrm{Lu}$ (2018) find mandatory adoption of IFRS is associated with higher provision of sales forecasts and cash flow forecasts, which is in line with Bilinski (2004)'s supply theory with the underlining assumption that earnings quality improved after IFRS adoption. Fang and Hope (2019) find that analyst teams are more likely to issue cash flow forecasts and use discounted cash flow valuation models in their reports. Further, teams with higher level of diversity tend to issue cash flow forecasts and use discounted cash flow valuation models in their reports. Fang and Hope (2019)'s findings also confirm supply theory in that analysts are more productive and are more specialized when they work in teams instead of individually.

In addition to the determinants of cash flow forecasts, prior research has also examined the consequences of providing those cash flow forecasts. Several studies have documented empirical evidence on the impact of cash flow forecasts availability on managerial behavior. McInnis and Collins (2011) investigate how managers react to analysts' cash flow forecasts and find management undertakes less accrual manipulation when cash flow forecasts are available. Lee (2012) finds that cash flow forecasts motivate managers to opportunistically increase 
reported operating cash flows. Ayers et al. (2018) find that analysts' cash flow forecasts give the managers the motivation to enhance the firm's cash flow position through tax avoidance activities.

Prior research also provides evidence on the impact of cash flow forecast availability and/or accuracy on analysts' forecasting performance and their career outcomes. Call et al. (2009) document that analysts' earnings forecasts are more accurate when analysts also provide cash flow forecasts, and they also find a negative association between cash flow forecast accuracy and brokerages' firing decisions, suggesting the benefits of providing cash flow forecasts. Lehavy (2009) and Givoly et al. (2009) and (2013) challenges the conclusion of Call et al. (2009) and provide empirical evidence suggesting that analysts' cash flow forecasts are of low quality in that they are simply adding back noncash items to its own earnings forecasts. Call et al. 2013), however, find that cash flow forecasts are of high quality in that analyst use disaggregate information in their cash flow forecasts.

Several studies have examined the impact of cash flow forecasts on capital market participants. Brown et al. (2013) show that firms that meet both earnings and cash flows forecasts have significantly higher abnormal stock returns around quarterly earnings announcement dates, compared to firms that meet only earnings forecasts but miss cash flows forecast. In addition, they find that firms missing earnings forecasts but meeting cash flows forecast experience significantly higher abnormal stock returns than firms missing both forecasts. Their evidence suggests that investors value cash flow forecasts. With U.S. data, both Mohanram (2014) and Radhkrishnan and $\mathrm{Wu}$ (2014) provide evidence on lower accrual anomaly for firmyears that at least one cash flow forecast is available. 
The research on cash flow forecasts outside of U.S is scarce. DeFond and Hung (2007) document that analysts are more motivated to issue cash flow forecasts in addition to earnings forecasts in code law countries where investor protection is low and earnings quality is relatively poor and cash flow forecasts are in high demand. Gordon and $\mathrm{Yu}$ (2014) find that the presence of analyst cash flow forecast reduces accrual anomaly and this mitigating effect is stronger for firms domiciled in countries with stronger investor protection. There is not much evidence about the quality and usefulness of cash flow forecasts outside of U.S. It is important to examine the usefulness of cash flow forecasts outside of U.S for several reasons. First, cash flow forecasts are more pervasive outside of U.S. Second, there are more variations of earnings quality both crosssectional and time-series, thus we can shed light on the debate of demand or supply theory on provision of cash flow forecasts.

\section{Hypotheses development}

\subsection{Overall international evidence}

Call et al. (2009) document that, in U.S., analysts' earnings forecasts are more accurate when accompanied with cash flow forecasts. We posit that their findings can extend to other countries. First, when analysts forecast cash flows, they are also forecasting a full set of financial statements. Call et al. (2009) argue that when analysts forecast cash flows, they adopt a structured approach to forecasting. This structured approach to forecasting financial statements imposes discipline on the earnings forecasts. Second, Hirshleifer and Teoh (2003) propose that, when the components of aggregated information exhibit different time-series properties and forecasting effort is concentrated on the individual components instead of the aggregated information, the resulting forecast of the aggregated information is more accurate. Thus, we posit the following hypothesis in the alternative form. 
H1: In an international setting, the issuance of analyst cash flow forecasts is associated with more accurate analyst earnings ' forecasts.

\subsection{Cross-sectional analyses}

Ball et al. (2000) develop the shareholder model of corporate governance that dominates in common law countries and the stakeholder model in code law countries. The former corporate governance system increases investor demand for analyst information whereas the stakeholder model is characterized by lower demand for public disclosure and stronger insider communication between management and various stakeholder groups.

Leuz et al. (2003) document that the earnings quality is higher in countries with common law and countries with higher disclosure. To the extent that earnings quality is higher in common law countries, the demand for analyst cash flow forecasts is expected to be lower in common law countries (DeFond and Hung 2007). Similarly, in the presence of more specific firm information, the demand for analyst cash flow forecasts is expected to be lower in countries with higher disclosure levels. We extend the above argument to the benefits of analyst cash flow forecasts given the equilibrium of the costs and benefits of demanding those cash flow forecasts. Thus, we posit the following hypothesis in the alternative form.

H2: In an international setting, the positive association between cash flow forecast issuance and earnings forecast accuracy is less pronounced in countries with higher disclosure levels.

\subsection{Time-series analyses utilizing the adoption of IFRS as an exogenous shock}

The adoption of IFRS was a major regulatory event affecting companies worldwide and it presents a useful context for our analyses for several reasons. First, from the analysts' perspective, mandatory IFRS adoption represents a significant exogenous shock to accounting standards in that it was outside of the control of analysts. Second, prior research on IFRS adoption has largely 
documented the benefits of IFRS, such as increase of financial reporting quality and increase in the usefulness of information to external users (e.g., Barth et al. 2008, Barth et al. 2012, Landsman et al. 2012, Yip and Young 2012, Lang and Stice-Lawrence 2015, Li and Yang 2015, Demmer et al. 2019). For instance, Barth et al. (2008) find that IAS voluntary adoption is associated with lower earnings management, more timely loss recognition, and greater value relevance, suggesting that IAS adoption increases accounting quality relative to local GAAP. Landsman et al. (2012) document that the information content of earnings announcements, proxied by either abnormal return volatility or abnormal trading volume, increases from pre- to post-adoption for firms in countries that mandate IFRS adoption relative to firms in countries that retain local GAAP, suggesting that IFRS earnings are perceived to be of higher quality than local GAAP earnings. Yip and Young (2012) document that IFRS adoption increases the financial reporting comparability for firms in European countries. Focusing on qualitative disclosure, Lang and Stice-Lawrence (2015) find that annual reports prepared under IFRS are significantly longer and contain less boilerplate language than non-IFRS annual reports and those reports prepared under IFRS are more comparable with each other than reports prepared under local GAAP, suggesting that mandatory IFRS adoption increases the quality of textual disclosures. Li and Yang (2015) document that firms are more likely to provide management earnings forecasts after IFRS adoption, suggesting that voluntary disclosure increased after IFRS adoption. Demmer et al. (2019) document significant out-of-sample improvement in financial statement-based forecast accuracy around mandatory IFRS adoption.

Taken together, prior studies have examined IFRS adoption and document that IFRS adoption has generally improved reporting quality, financial statement comparability, qualitative disclosures in financial reports, voluntary disclosures, and facilitated fundamental analysis by 
external users. The increases in both quantity and quality of firm-specific information will presumably help external users in their decision making. Consistent with this notion, Demmer et al. (2019) document a positive association between analyst forecast accuracy and the improvement in financial statement-based forecast accuracy around IFRS adoption.

The increases in financial reporting quality and the availability of more firm-specific information affect both the demand and effects of analysts' cash flow forecasts. For example, De Franco et al. (2011) argue that comparability decreases information acquisition and processing costs and increases the overall quantity and quality of information, thereby enhancing the investors and other external users' ability to understand and predict economic events. To the extent that IFRS adoption has improved information environment of firms, we predict that the usefulness of cash flow forecasts to analysts' themselves in forecasting future earnings will be less pronounced in the post-IFRS relative to pre-IFRS adoption period. Therefore, we predict that the positive association between analyst cash flow forecast issuance and earnings forecast accuracy will be weaker after IFRS. We propose the following hypothesis in the alternative form:

H3: The positive association between cash flow forecast issuance and earnings forecast accuracy is weaker post-IFRS as opposed to pre-IFRS adoption.

\section{Research design}

To test H1, we follow Call et al. (2009)'s model as follows.

$$
\begin{aligned}
& M A F E_{i j c t}=\alpha+\beta_{1} C F F_{i j c t}+\beta_{2} L M A F E_{i j c t}+\beta_{3} M A G E_{i j c t}+\beta_{4} M F R E Q_{i j c t}+\beta_{5} M F E X P_{i j c t}+ \\
& \beta_{6} M G E X P_{i t}+\beta_{7} D T O P 10_{i t}+\beta_{8} M N C O S_{i t}+\beta_{9} M N S I C 2_{i t}+\sum_{\mathrm{c}} \text { Country }_{c}+\sum_{\mathrm{t}} \text { Year }_{t}+\varepsilon_{i j c t}
\end{aligned}
$$

Where: 
$M A F E_{i j c t}=$ Mean-adjusted earnings forecast accuracy, calculated as the negative value of analyst $i$ 's absolute forecast error for firm $j$ in year $t$ minus mean absolute forecast error across all analysts following firm $j$ in year $t$;

$C F F_{i j c t}=1$ if analyst $i$ issues both cash flow and earnings forecasts for firm $j$ in year $t$, and 0 if analyst $i$ only issues earnings forecasts for firm $j$ in year $t$; $L M A F E_{i j c t}=$ One period lagged of $M A F E_{i j c t} ;$ $M A G E_{i j c t}=$ Mean-adjusted number of days between analyst $i$ 's earnings forecast date and the actual earnings announcement date for firm $j$ in year $t$; $M F R E Q_{i j c t}=$ Mean-adjusted number of distinct earnings forecasts made by analyst $i$ for firm $j$ in year $t$ $M_{\text {MEXP }}{ }_{i j c t}=$ Mean-adjusted number of years for which analyst $i$ has supplied at least one earnings forecast for firm $j$, prior to year $t$; $M_{G E X P_{i t}}=$ Mean-adjusted number of years for which analyst $i$ has supplied at least one earnings forecast for any firm, prior to year $t$; $D T O P 10_{i t}=1$ if analyst $i$ is employed by a brokerage house in the top size decile during year $t$, and 0 otherwise. Size deciles are based on the number of unique analysts employed in year $t$; $M N C O S_{i t}=$ Mean-adjusted number of distinct firms for which analyst $i$ makes at least one earnings forecast during year $t$; $M N S I C 2_{i t}=$ Mean-adjusted number of distinct industries (based on two-digit SIC codes) for which analyst $i$ makes at least one earnings forecast during year $t$; Country $_{c}=$ Country fixed effects; Year ${ }_{t}=$ Year fixed effects. 
Consistent with Call et al. (2009), we use mean-adjusted measures of analyst variables (i.e., $M F R E Q_{i j c t}, M F E X P_{i j c t}, M G E X P_{i j c t}, M N C O S_{i j c t}$, and $\left.M N S I C 2_{i j c t}\right)$ to control for variations in forecasting characteristics across firm and across year. We expect the coefficient on $C F F_{i j t}$ to be positive to support $\mathrm{H} 1$.

To test $\mathrm{H} 2$, we interact country variables of interest with $C F F_{i j t}$ as follows.

$M A F E_{i j c t}=\alpha+\beta_{1} C F F_{i j c t}+\beta_{2} C F F_{i j c t} \times$ CountryVariable $_{c}+\beta_{3} L M A F E_{i j c t}+\beta_{4} M A G E_{i j c t}+$ $\beta_{5} M_{F R E Q_{i j c t}}+\beta_{6} M F E X P_{i j c t}+\beta_{7} M G E X P_{i t}+\beta_{8} D T O P 10_{i t}+\beta_{9} M N C O S_{i t}+\beta_{10 M N S I C 2_{i t}}+$

$\sum_{\mathrm{c}}$ Country $_{c}+\sum_{\mathrm{t}}$ Year $_{t}+\varepsilon_{i j c t}$

Where:

CountryVariable $_{c}=$ ANTI_DIR (anti-director rights), LEGAL (legal origin), or ENFORCE (enforcement index), or DISC (disclosure level).

Other variables are defined the same as Model (1). We expect $C F F_{i j t} \times$ CountryVariable $_{c}$ to be negative and significant to support $\mathrm{H} 2$.

To test H3, we follow prior studies (e.g., DeFond et al. 2007, Landsman et al. 2012, Demmer et al. 2019) and use a difference-in-differences research design. Different from prior studies that focus on the mandatory adoption of IFRS in the European Union, which has the same adoption year of 2005, and use the firms from non-adoption countries as control firms. In those studies, there are two time periods (Pre- and Post-adoption) and two groups (i.e., adoption countries and non-adoption countries). With the single adoption year, the standard difference-indifferences model can estimate the average treatment effect for the adoption by comparing the average change in outcomes experienced by the observations in adoption countries to the average change in outcomes experienced by the observations from non-adoption countries.

$Y_{\text {ict }}=\alpha+\gamma *$ Adopt $_{c}+\lambda$ Post $_{t}+\delta *\left(\right.$ Adopt $_{c} *$ Post $\left._{t}\right)+\epsilon_{\text {ict }}$ 
Where:

$A d o p t_{c}=$ a dummy which is equal to 1 if the observation is from the Adoption countries.

Post $_{t}=$ a dummy which is equal to 1 in the time period after the adoption.

Thus, $\alpha$ captures the average effect of control group or non-adoption countries, before adoption; $\alpha+\lambda$ captures the average effect of control group or non-adoption countries, after adoption; $\alpha+\gamma$ captures the average effect of treatment group or adoption countries, before adoption; $\alpha+\gamma+\lambda+\delta$ captures the average effect of treatment group or adoption countries, after adoption. Hence, in a two-period model, the difference in differences estimate is $\delta$, which is the same as $[(\alpha+\gamma+\lambda+\delta-\alpha+\gamma)-(\alpha+\lambda-\alpha)]$ and estimate the average treatment effect for the adoption.

However, with more and more countries adopting IFRS over time in our sample period, the standard difference-in-differences model based on single adoption period is not applicable. Therefore, we follow prior economic research studies (e.g. Bertrand and Schoar 2003; Wolfers 2006) and use the "two-way fixed effects" regression model. Specifically, we build on the following two-way fixed effects model.

$Y_{i c t}=\alpha+\gamma * \operatorname{IFRS}_{c, t}+\sum_{c}$ Country $_{c}+\sum_{t}$ Year $_{t}+\epsilon_{i c t}$

The variable IFRS $\mathrm{c}_{\mathrm{c}, \mathrm{t}}$ is a dummy variable, set equal to one when the country is under IFRS reporting standard, and zero under non-IFRS reporting standard. The coefficient $\gamma$ is interpreted as the average change in the outcome attributable to the adoption of IFRS.

Since we are interested in whether the relation between the provision of analyst cash flow forecasts $(C F F)$ and analyst earnings forecast accuracy $(M A F E)$ changes after the adoption of IFRS, the model is specified as follows. 


$$
\begin{aligned}
& \text { MAFE }_{i j c t}=\alpha+\beta_{1} \text { CFF }_{i j c t}+\beta_{2} \text { IFRS }_{c, t}+\beta_{3} C F F_{i j c t} \times I F R S_{c, t}+\beta_{4} L M A F E_{i j c t}+\beta_{5} M A G E_{i j c t}+ \\
& \beta_{6} M_{F R E Q_{i j c t}}+\beta_{7} \text { MFEXP }_{i j c t}+\beta_{8} M G E X P_{i t}+\beta_{9} D T O P 10_{i t}+\beta_{10} M_{N C O S}+\beta_{11} M N S I C 2_{i t}+ \\
& \sum_{c} \text { Country }_{c}+\sum_{t} \text { Year }_{t}+\varepsilon_{i j c t}
\end{aligned}
$$

We expect $C F F_{i j c t} \times I F R S_{c, t}$ in Model (5) to be negative and significant to support H3.

\section{Data and sample}

We first collect data from I/B/E/S International file over January 1994 to December 2018. Our sample period starts from 1995 because analysts' cash flow forecasts started to be available in $\mathrm{I} / \mathrm{B} / \mathrm{E} / \mathrm{S}$ from 1995. Our sample period ends December 2018 because it is the most recent data available on I/B/E/S as we collected our data analysis. For our initial sample, we collect $5,624,432$ individual analyst earnings forecasts over our sample period. We use the Daily Exchange Rate file from $\mathrm{I} / \mathrm{B} / \mathrm{E} / \mathrm{S}$ database to translate forecasted earnings per share and cash flow per share, as well as actual earnings per share and cash flow per share from all currencies into U.S. dollars.

We then merge with Compustat Global to collect the following variables. First, we obtain SIC code (to calculate one of the explanatory variables, i.e., MNSIC $2_{i j t}$ ). Second, we collect country in which the firms, for which analysts provide earnings forecasts, are domiciled in (variable name $=$ LOC). Third, we collect the accounting standard the firm uses in presenting its financial statements (variable name $=$ ACCTSTD). Merging with Compustat Global reduced our sample to 3,866,675 analyst-firm-year observations. As we use the most recent earnings forecasts of each analyst-year, we further reduced the sample to 1,375,627 analyst-firm-year observations (i.e., individual analyst earnings forecasts), representing 55,787 distinct analysts forecasting for firms domiciled in 85 countries. We further deleted observations from countries that have less than 100 observations in the sample. Since we require the lagged measure of 
analyst forecast error, our sample used to test our H1 and H3 includes 555,014 observations, representing observations from 55 countries and span from fiscal year 1995 to 2018. Of these 555,014 individual earnings forecasts, 178,445 are accompanied with cash flow forecasts and 376,559 observations are not.

Country-level variables from DeFond and Hung (2007) are only available for 33 countries. Thus, our cross-country sample is restricted to 493,399 observations from 33 countries.

Table 1 displays the sample distribution across countries, and also list whether countries have adopted IFRS (if yes, then the year of adoption becoming effective) or not. For those countries that have the country-level investor protection variables (Anti-director rights, legal origin, and enforcement indexes) and disclosure level variable, we also list those values.

[Insert Table 1 about here.]

Table 2 compares the means and medians of key variables. In Panel A, we compare the means and medians of raw values of explanatory variables. In Panel B, we compare the means and medians of mean-adjusted values of explanatory variables as well as our dependent variable. We provide p-values of t-statistics (z-statistics) from our t-tests (Wilcoxon tests) of mean (median) differences. Our tests of differences in means and medians for explanatory variables suggest that the analyst features are significantly different across our two subsamples: with and without cash flow forecasts. Therefore, controlling for analyst characteristics are necessary when comparing their earnings forecast accuracy.

[Insert Table 2 about here.]

The mean of $M A F E_{i j t}$ is 0.039 for our subsample of earnings forecasts accompanied with cash flow forecasts whereas the mean of $M A F E_{i j t}$ is 0.022 for our subsample of earnings forecasts 
without cash flow forecasts. The two-sample $t$ test results suggest that the mean of $M A F E_{i j t}$ is significantly larger for the subsample with cash flow forecasts. The median of $M A F E_{i j t}$ is 0.216 for our subsample of earnings forecasts accompanied with cash flow forecasts whereas the median of $M A F E_{i j t}$ is 0.185 for our subsample of earnings forecasts without cash flow forecasts. The Wilcoxon test results suggest that the median of $M A F E_{i j t}$ is significantly larger for our subsample with cash flow forecasts. Taken together, our univariate tests provide preliminary evidence on the higher accuracy of earnings forecasts when cash flow forecasts are provided. To control for analyst characteristics and firm characteristics that might affect the accuracy of earnings forecasts, we provide multivariate regression results in the next section.

\section{Empirical results}

Prior research that involves individual analyst forecasts use a variety of ways to address the interdependence among firms and years (e.g., Gleason and Lee 2003, Call et al. 2009, Hashim and Strong 2018). Consistent with prior research, we calculate analyst-clustered standard errors to control for time-series dependence in earnings forecast accuracy (Petersen 2009). Consistent with DeFond and Hung (2007), we control for year fixed effects. Finally, because our sample is composed of multiple countries, we therefore also control for country fixed effects.

In Panel A of Table 3, we present results of H1 with our whole sample of 555,014 forecast-level observations. The t-statistics are robust and clustered at analyst level. The coefficient on $C F F_{i j c t}$ is positive and significant $($ coefficient estimate $=0.0099$, t-value $=2.93$, suggesting a positive association between the provisions of cash flow forecasts and earnings forecast accuracy in an international setting. Therefore, $\mathrm{H} 1$ is supported. Our international results are consistent with Call et al. (2009)'s finding in U.S. that earnings forecasts supplemented with cash flow forecasts are more accurate than those without cash flow forecasts. $L M A F E_{i j c t}$, 

1994-2018 that analysts' cash flow forecast provisions improve their own earnings forecasts, the results in Table 5 indicate that our whole sample results are mainly driven by pre-IFRS period.

[Insert Table 5 about here.]

\section{Sensitivity tests and additional analyses}

\subsection{Using all individual analyst forecasts}

In our main tests, we follow Call et al. (2009) and only include the most recent earnings forecasts (and cash flow forecasts if cash flow forecasts are also provided on that day) and remove all other individual forecasts. Therefore, our results may only reflect the increased accuracy of most recent earnings forecasts, but not all earnings forecasts, due to the provisions of cash flow forecasts. In our sensitivity tests, we include all individual forecasts. Our results are unchanged.

\subsection{Using same analyst different firms}

Prior research that has run the regressions with individual analyst forecasts as the unit of observations has alternatively run the regressions at the analyst level, i.e., use same analyst different firms. (e.g., Gleason and Lee 2003, Call et al. 2009, Hashim and Strong 2018). We ran our regressions at the analyst level and find our results are consistent with our main results.

\subsection{Exploring earnings quality improvement as a reason for improved earnings forecast} accuracy

When analysts issue cash flow forecasts, investors can decompose unexpected earnings into unexpected cash flows and abnormal accruals. McInnis and Collins (2011) show that instances of companies meeting cash flow targets but missing earnings targets are rare, suggesting that the availability of cash flow forecasts does not make firms shift their focus to meeting cash flow targets. Therefore, cash flow forecast availability should help investors assess 
if firms are manipulating earnings. If cash flow forecast availability reduces earnings management by disciplining managers, earnings quality should improve. We are motivated to test whether earnings quality is improved due to cash flow forecast provisions as an explanation of improved earnings forecasts.

\section{Conclusions}

In this paper, we examine one of the consequences of cash flow forecast provisions, which is in terms of improving analysts' own earnings forecasts, in an international setting. Our international results support our prediction that the issuance of cash flow forecasts is positively associated with earnings forecast accuracy of those analysts. In other words, earnings forecast accuracy is significantly higher for those forecasts accompanied with cash flow forecasts, relative to those not accompanied with cash flow forecasts. Furthermore, the association between cash flow forecast provisions and earnings forecast accuracy is weaker for firms domiciled in countries with higher disclosure level. Finally, the association between cash flow forecast provisions and earnings forecast accuracy is weaker after IFRS adoption when earnings are in higher quality. Therefore, forecasting cash flow is not as useful to analysts' own earnings prediction in an environment with high quality disclosure and in the presence of more and higher quality firm-specific information induced by IFRS. 


\section{REFERENCES}

Ashbaugh, H., \& Pincus, M. 2001. Domestic accounting standards, international accounting standards, and the predictability of earnings. Journal of Accounting Research 39 (3): 417-434.

Ayers, Benjamin, Andrew Call, and Casey Schwab. 2018. Do analysts' cash flow forecasts encourage managers to improve the firms' cash flow forecasts? Evidence from tax planning. Contemporary Accounting Research 35 (2): 767-793.

Ball, R., S. P. Kothari, and A. Robin. 2000. The effect of international institutional factors of properties of accounting earnings. Journal of Accounting and Economics 29 (1): 1-51.

Barniv, Ran, Mark Myring, and Wayne Thomas. 2005. The association between the legal and financial reporting environments and forecast performance of individual analysts. Contemporary Accounting Research 22 (4): 727-758.

Bertrand, Marianne, and Antoinette Schoar. 2003. Managing with style: The effect of managers on firm policies. Quarterly Journal of Economics 118 (4): 1169-1208.

Bilinski, P. 2014. Do analysts disclose cash flow forecasts with earnings estimates when earnings quality is low? Journal of Business Finance and Accounting 41 (3-4): 401-434.

Bradshaw, M., S. Richardson, and R. Sloan. 2001. Do analysts and auditors use information in accruals? Journal of Accounting Research 39 (1): 45-74.

Brown, Lawrence, Kelly Huang and Arianna Pinello. 2013. To beat or not to beat? The importance of analysts' cash flow forecasts. Review of Quantitative Finance and Accounting 41 (4): 723-752.

Byard, Donal, Ying Li, and Yong Yu. 2011. The effect of mandatory IFRS adoption on financial analysts' information environment. Journal of Accounting Research 49 (1): 69-96.

Call, Andrew, Shuping Chen, and Yen Tong. 2009. Are analysts' earnings forecasts more accurate when accompanied by cash flow forecasts? Review of Accounting Studies 14 (2-3): 358391.

Call, Andrew, Shuping Chen, and Yen Tong. 2013. Are analysts' cash flow forecasts naïve extensions of their own earnings forecasts? Contemporary Accounting Research 30 (2): 438-465.

Clement, M., L. Rees, and E. Swanson. 2003. The influence of culture and corporate governance on the characteristics that distinguish superior analysts. Journal of Accounting, Auditing and Finance 18 (4): 593-609.

DeFond, Mark, and Mingyi Hung. 2003. An empirical analysis of analysts' cash flow forecasts. Journal of Accounting and Economics 35 (1): 73-100. 
DeFond, Mark, and Mingyi Hung. 2007. Investor protection and analysts' cash flow forecasts around the world. Review of Accounting Studies 12 (2-3): 377-419.

DeFond, Mark, Mingyi Hung and Robert Trezevant. 2007. Investor protection and the information content of annual earnings announcements: International evidence. Journal of Accounting and Economics 43 (1): 37-67.

DeFond, M., X. Hu, M. Hung, and S. Li. 2011. The impact of mandatory IFRS adoption on foreign mutual fund ownership: The role of comparability. Journal of Accounting and Economics 51 (3): 240-258.

Demmer, Matthias, Paul Pronobis, and Teri Lombardi Yohn. 2019. Mandatory IFRS adoption and analyst forecast accuracy: the role of financial statement-based forecasts and analyst characteristics. Review of Accounting Studies 24 (3): 1022-1065.

Ertimur, Y., and S. Stubben. 2005. Analysts' incentives to issue revenue and cash flow forecasts. Working paper.

Fang, Bingxu and Hope, Ole-Kristian. 2020. Analyst teams. Review of Accounting Studies. Forthcoming.

Gordon, E., K. Petruska, and M Yu. 2014. Do analysts' cash flow forecasts mitigate the accrual anomaly? International evidence. Journal of International Accounting Research 13 (1): 61-90.

He, Wen, and Chien-Ju Lu. 2018. Why do analysts issue sales forecasts? Evidence from mandatory IFRS adoption. Accounting Horizons 32 (1): 121-141.

Hope, Ole-Kristian. 2003. Disclosure practices, enforcement of accounting standards, and analysts' forecast accuracy: An international study. Journal of Accounting Research 41 (2): 235272.

Horton, J., G. Serafeim, and I. Serafeim. 2013. Does mandatory IFRS adoption improve the information environment? Contemporary Accounting Research 30 (1): 388-423.

Isidro, Helena, Dhananjay Nanda, and Peter Wysocki. 2020. On the relation between financial reporting quality and country attributes: Research challenges and opportunities. Accounting Review. Forthcoming.

La Porta, R., F. Lopez-De-Silanes, A. Shlfifer, and R. Vishny. 1998. Law and Finance. Journal of Political Economy 106 (6): 1113-1155.

Lee, L. F. 2012. Incentives to inflate reported cash from operations using classification and timing. The Accounting Review 87 (1): 1-33.

McInnis and Collins. 2011. The effect of cash flow forecasts on accrual quality and benchmark beating. Journal of Accounting and Economics 51 (3): 219-239. 
Petersen, M. 2009. Estimating standard errors in finance panel data sets: Comparing approaches. Review of Financial Studies 22 (1): 435-480.

Rajgopal, S., Shevlin, T., and M. Venkatachalam. 2003. Does the stock market fully appreciate the implications of leading indicators of future earnings? Evidence from order backlog. Review of Accounting Studies 8 (4): 461-492.

Tan, Hongping, Shiheng Wang and Mike Welker. 2011. Analyst Following and Forecast Accuracy after Mandated IFRS Adoptions. Journal of Accounting Research 49 (5): 1307-1357.

Wolfers, Justin. 2006. Did Unilateral Divorce Raise Divorce Rates? A Reconciliation and New Results. American Economic Review 96 (5): 1802-1820. 


\section{Appendix: Variable definitions}

\begin{tabular}{|c|c|}
\hline$A F E_{i j c t}$ & $\begin{array}{l}\text { Earnings forecast accuracy, calculated as the negative value of analyst } i \text { 's absolute } \\
\text { forecast error for firm } j \text { of country c in year } t \text {. }\end{array}$ \\
\hline$A G E_{i j c t}$ & $\begin{array}{l}\text { Number of days between analyst i's earnings forecast date and the actual earnings } \\
\text { announcement date for firm } j \text { of country c in year } t \text {. }\end{array}$ \\
\hline FREQ $Q_{i j c t}$ & Number of distinct earnings forecasts made by analyst $i$ for firm $j$ of country $\mathrm{c}$ in year $t$. \\
\hline$F E X P_{i j c t}$ & $\begin{array}{l}\text { Number of years for which analyst } i \text { has supplied at least one earnings forecast for firm } j \\
\text { of country c, prior to year } t \text {. }\end{array}$ \\
\hline$G E X P_{i t}$ & $\begin{array}{l}\text { Number of years for which analyst } i \text { has supplied at least one earnings forecast for any } \\
\text { firm, prior to year } t \text {. }\end{array}$ \\
\hline$N_{C O S}$ & $\begin{array}{l}\text { Number of distinct firms for which analyst } i \text { makes at least one earnings forecast during } \\
\text { year } t \text {. }\end{array}$ \\
\hline$N S I C_{i t}$ & $\begin{array}{l}\text { Number of distinct industries (based on two-digit SIC codes) for which analyst } i \text { makes } \\
\text { at least one earnings forecast during year } t \text {. }\end{array}$ \\
\hline$M A F E_{i j c t}$ & $\begin{array}{l}\text { Mean-adjusted earnings forecast accuracy, calculated as the negative value of analyst } i \text { 's } \\
\text { absolute forecast error for firm } j \text { of country c in year } t \text { minus mean absolute forecast } \\
\text { error across all analysts following firms in year } t \text {. }\end{array}$ \\
\hline$C F F_{i j c t}$ & $\begin{array}{l}\text { Equals } 1 \text { if analyst } i \text { issues both cash flow and earnings forecasts for firm } j \text { of country c } \\
\text { in year } t \text {, and } 0 \text { if analyst } i \text { only issues earnings forecasts for firm } j \text { in year } t \text {. }\end{array}$ \\
\hline$L M A F E_{i j c t}$ & One period lagged mean-adjusted earnings forecast error. \\
\hline$M A G E_{i j c t}$ & $\begin{array}{l}\text { Mean-adjusted number of days between analyst i's earnings forecast date and the actual } \\
\text { earnings announcement date for firm } j \text { of country c in year } t \text {. }\end{array}$ \\
\hline$M F R E Q_{i j c t}$ & $\begin{array}{l}\text { Mean-adjusted number of distinct earnings forecasts made by analyst } i \text { for firm } j \text { of } \\
\text { country c in year } t \text {. }\end{array}$ \\
\hline$M F E X P_{i j c t}$ & $\begin{array}{l}\text { Mean-adjusted number of years for which analyst } i \text { has supplied at least one earnings } \\
\text { forecast for firm } j \text { of country } \mathrm{c} \text {, prior to year } t \text {. }\end{array}$ \\
\hline$M G E X P_{i t}$ & $\begin{array}{l}\text { Mean-adjusted number of years for which analyst } i \text { has supplied at least one earnings } \\
\text { forecast for any firm, prior to year } t \text {. }\end{array}$ \\
\hline$D^{2} O P 10_{i t}$ & $\begin{array}{l}\text { Equals } 1 \text { if analyst } i \text { is employed by a brokerage house in the top size decile during year } \\
t \text {, and } 0 \text { otherwise. Size deciles are based on the number of unique analysts employed in } \\
\text { year } t \text {. }\end{array}$ \\
\hline $\operatorname{MNCOS}_{i t}$ & $\begin{array}{l}\text { Mean-adjusted number of distinct firms for which analyst } i \text { makes at least one earnings } \\
\text { forecast during year } t \text {. }\end{array}$ \\
\hline$M N S I C_{i t}$ & $\begin{array}{l}\text { Mean-adjusted number of distinct industries (based on two-digit SIC codes) for which } \\
\text { analyst } i \text { makes at least one earnings forecast during year } t \text {. }\end{array}$ \\
\hline$L E G A L_{c}$ & $\begin{array}{l}\text { Equals } 1 \text { when the country has common law origin, } 0 \text { when the country has code law } \\
\text { origin. }\end{array}$ \\
\hline$A N T I \_D I R_{c}$ & $\begin{array}{l}\text { The anti-director rights index constructed by La Porta et al. (1998). The index, based on } \\
\text { company laws or commercial codes, aggregates the following aspects of investor rights: } \\
\text { (1) the ability to vote by mail, (2) the ability to gain control of shares during investors' } \\
\text { meetings, (3) the possibility of cumulative voting for directors, (4) the ease of calling an } \\
\text { extraordinary investors meeting, (5) the availability of mechanisms allowing minority } \\
\text { investors to make legal claims against the directors, and (6) the presence of } \\
\text { shareholders' preemptive rights that can be waived only by a shareholders' vote. The } \\
\text { index ranges from } 0 \text { to 5, with higher scores indicating stronger shareholder rights. }\end{array}$ \\
\hline $\mathrm{ENFORCE}_{c}$ & $\begin{array}{l}\text { An index based on the mean score of three legal enforcement variables } \\
\text { reported in La Porta et al. (1998). The three variables are (1) efficiency of the judicial } \\
\text { system, which assesses the efficiency and integrity of the legal environment and is } \\
\text { based on the average of 1980-1983 data from Business International Corp., (2) rule of }\end{array}$ \\
\hline
\end{tabular}




\begin{tabular}{|l|l|}
\hline & $\begin{array}{l}\text { law, which assesses the rule and order tradition in a country and is based on the average } \\
\text { of 1982-1995 data from International Country Risk, and (3) corruption, which assesses } \\
\text { the corruption in government. The index ranges from 0 to 10, with higher scores } \\
\text { indicating greater law enforcement, based on the average of 1982-1995 data from } \\
\text { International Country Risk. }\end{array}$ \\
\hline$D I S C_{c}$ & $\begin{array}{l}\text { An index developed for each country by the Center for International Financial } \\
\text { Analysis and Research (CIFAR, 1995). The index represents the average percentage of } \\
85 \text { items included in the 1993 annual reports of a sample of domestic companies for } \\
\text { each country, where higher scores equal greater disclosure. }\end{array}$ \\
\hline$I F R S_{c t}$ & $\begin{array}{l}\text { Equals 1 when the country is under IFRS reporting standard, and 0 under non-IFRS } \\
\text { reporting standard. }\end{array}$ \\
\hline
\end{tabular}


Table 1: Sample distribution across countries, country's IFRS adoption year and country-level variables from La Porta et al. (1998) and DeFond and Hung (2007), and sample across year.

Panel A: Sample distribution across countries, country's IFRS adoption year and country-level variables

\begin{tabular}{|c|c|c|c|c|c|c|}
\hline Country name & Obs & IFRS Adoption & ANTI_DIR & $L E G A L$ & ENFORCE & DISC \\
\hline United Arab Emirates (the) & 471 & 2015 & & & & \\
\hline Argentina & 1,666 & 2012 & 4 & 1 & 5.79 & 68 \\
\hline Australia & 28,290 & 2005 & 4 & 1 & 9.51 & 80 \\
\hline Austria & 3,455 & 2005 & 2 & 0 & 9.36 & 62 \\
\hline Belgium & 5,699 & 2005 & 0 & 0 & 9.44 & 68 \\
\hline Bermuda & 1,015 & No & & & & \\
\hline Brazil & 4,765 & 2010 & 3 & 0 & 6.13 & 56 \\
\hline Chile & 1,949 & 2009 & 5 & 0 & 6.52 & 78 \\
\hline China & 26,709 & No & & & & \\
\hline Columbia & 152 & 2015 & 3 & 0 & 4.78 & 58 \\
\hline Czechia & 1,014 & 2005 & & & & \\
\hline Denmark & 4,891 & 2005 & 2 & 0 & 10 & 75 \\
\hline Egypt & 611 & No & & & & \\
\hline Finland & 10,292 & 2005 & 3 & 0 & 10 & 83 \\
\hline France & 36,713 & 2005 & 3 & 0 & 8.68 & 78 \\
\hline Germany & 38,550 & 2005 & 1 & 0 & 9.05 & 67 \\
\hline Greece & 3,848 & 2005 & 2 & 0 & 6.82 & 61 \\
\hline Hong Kong & 25,506 & 2005 & 5 & 1 & 8.91 & 73 \\
\hline Croatia & 104 & No & & & & \\
\hline Hungary & 1,062 & No & & & & \\
\hline Indonesia & 4,963 & No & & & & \\
\hline India & 18,704 & No & 5 & 1 & 5.58 & 61 \\
\hline Ireland & 1,657 & 2005 & 4 & 1 & 8.36 & 81 \\
\hline Israel & 1,168 & 2008 & & & & \\
\hline Italy & 13,386 & 2005 & 1 & 0 & 7.07 & 66 \\
\hline Japan & $\begin{array}{c}110,60 \\
9\end{array}$ & No & 4 & 0 & 9.17 & 71 \\
\hline Kenya & 124 & 1999 & & & & \\
\hline Korea & 19,330 & 2011 & 2 & 0 & 5.55 & 68 \\
\hline Kuwait & 258 & 1990 & & & & \\
\hline Sri Lanka & 400 & 2012 & & & & \\
\hline Luxembourg & 637 & 2005 & & & & \\
\hline Morocco & 215 & No & & & & \\
\hline Malaysia & 18,374 & 2012 & 4 & 1 & 7.72 & 79 \\
\hline Mexico & 4,554 & 2012 & 1 & 0 & 5.37 & 71 \\
\hline
\end{tabular}




\begin{tabular}{|l|c|c|c|c|c|c|}
\hline Nigeria & 575 & 2012 & & & & \\
\hline Netherlands & 11,586 & 2005 & 2 & 0 & 10 & 74 \\
\hline New Zealand & 3,144 & 2007 & 4 & 1 & 10 & 80 \\
\hline Norway & 7,030 & 2005 & 4 & 0 & 10 & 75 \\
\hline Pakistan & 882 & 2007 & 5 & 1 & 3.67 & 73 \\
\hline Peru & 391 & 2012 & & & & \\
\hline Philippines & 3,386 & 2005 & 3 & 0 & 3.47 & 64 \\
\hline Papua New Guinea & 456 & 1998 & & & & \\
\hline Poland & 3,192 & 2005 & & & & \\
\hline Portugal & 1,615 & 2005 & 3 & 0 & 7.19 & 56 \\
\hline Qatar & 532 & 2002 & & & & \\
\hline Romania & 137 & 2005 & & & & \\
\hline Russian Federation (the) & 268 & 2012 & & & & \\
\hline Singapore & 11,351 & 2003 & 4 & 1 & 8.93 & 79 \\
\hline South Africa & 6,545 & 2005 & 5 & 1 & 6.45 & 79 \\
\hline Spain & 11,240 & 2005 & 4 & 0 & 7.14 & 72 \\
\hline Slovenia & 162 & 2005 & & & & \\
\hline Sweden & 9,626 & 2005 & 3 & 0 & 10 & 83 \\
\hline Switzerland & 13,216 & 2005 & 2 & 0 & 10 & 80 \\
\hline Thailand & 6,778 & No & 2 & 1 & 4.89 & 66 \\
\hline Taiwan (Province of China) & 17,151 & 2013 & & & & \\
\hline UK & 54,610 & 2005 & 5 & 1 & 9.22 & 85 \\
\hline
\end{tabular}

LEGAL and ENFORCE is from La Porta et al. (1998) and DISC is from DeFond and Hung (2007).

Panel B: Sample distribution across year

\begin{tabular}{|c|c|c|l|c|c|c|}
\hline Year & Frequency & Percent & & Year & Frequency & Percent \\
\hline 1995 & 11,586 & 2.09 & & 2007 & 23,494 & 4.23 \\
\hline 1996 & 14,409 & 2.60 & & 2008 & 24,007 & 4.33 \\
\hline 1997 & 19,012 & 3.43 & & 2009 & 23,881 & 4.30 \\
\hline 1998 & 19,070 & 3.44 & & 2010 & 25,665 & 4.62 \\
\hline 1999 & 20,307 & 3.66 & & 2011 & 27,194 & 4.9 \\
\hline 2000 & 22,169 & 3.99 & & 2012 & 27,109 & 4.88 \\
\hline 2001 & 20,828 & 3.75 & & 2013 & 27,669 & 4.99 \\
\hline 2002 & 22,781 & 4.10 & & 2014 & 27,848 & 5.02 \\
\hline 2003 & 21,428 & 3.86 & & 2015 & 28,366 & 5.11 \\
\hline 2004 & 23,306 & 4.20 & & 2016 & 26,934 & 4.85 \\
\hline 2005 & 23,206 & 4.18 & & 2017 & 26,503 & 4.78 \\
\hline 2006 & 23,076 & 4.16 & & 2018 & 25,166 & 4.53 \\
\hline
\end{tabular}


Table 2: Summary statistics of key variables

Panel A: Mean and median differences of raw values of variables

\begin{tabular}{|c|c|c|c|c|c|c|}
\hline & $\begin{array}{c}\text { Mean } \\
C F F_{i j c t}=1\end{array}$ & $\begin{array}{c}\text { Mean } \\
C F F_{i j c t}=0\end{array}$ & $\begin{array}{c}\text { Difference in } \\
\text { means } \\
\text { (p-value } \\
\text { from } t \text { test) }\end{array}$ & $\begin{array}{c}\text { Median } \\
C F F_{i j c t}=1\end{array}$ & $\begin{array}{c}\text { Median } \\
C F F_{i j c t}=0\end{array}$ & $\begin{array}{c}\text { Difference in } \\
\text { medians } \\
\text { (p-value from } \\
\text { Wilcoxon test) }\end{array}$ \\
\hline$A F E_{i j c t}$ & 0.681 & 13.635 & $<0.001$ & 0.060 & 0.039 & $<0.001$ \\
\hline$A G E_{i j c t}$ & 115.386 & 123.898 & $<0.001$ & 90.000 & 95.000 & $<0.001$ \\
\hline$F R E Q_{i j c t}$ & 3.704 & 3.240 & $<0.001$ & 3.000 & 3.000 & $<0.001$ \\
\hline$F E X P_{i j c t}$ & 3.510 & 3.321 & $<0.001$ & 2.000 & 2.000 & $<0.001$ \\
\hline$G E X P_{i j c t}$ & 6.832 & 6.191 & $<0.001$ & 6.000 & 5.000 & $<0.001$ \\
\hline DTOP10 & 0.662 & 0.583 & $<0.001$ & 1.000 & 1.000 & $<0.001$ \\
\hline$N C O S_{i t}$ & 8.450 & 9.908 & $<0.001$ & 7.000 & 7.000 & $<0.001$ \\
\hline$N S I C 2_{i t}$ & 3.681 & 3.820 & $<0.001$ & 3.000 & 3.000 & $<0.001$ \\
\hline$N$ & 178,455 & 376,559 & & 178,455 & 376,559 & \\
\hline
\end{tabular}

Panel B: Mean and median differences of mean-adjusted values of variables

\begin{tabular}{|c|c|c|c|c|c|c|}
\hline & $\begin{array}{c}\text { Mean } \\
C F F_{i j c t}=1\end{array}$ & $\begin{array}{c}\text { Mean } \\
C F F_{i j c t}=0\end{array}$ & $\begin{array}{c}\text { Difference in } \\
\text { means } \\
\text { ( } p \text {-value } \\
\text { from } t \text { test) }\end{array}$ & $\begin{array}{c}\text { Median } \\
C F F_{i j c t}=1\end{array}$ & $\begin{array}{c}\text { Median } \\
C F F_{i j c t}=0\end{array}$ & $\begin{array}{c}\text { Difference in } \\
\text { medians } \\
\text { (p-value from } \\
\text { Wilcoxon test) }\end{array}$ \\
\hline$M A F E_{i j c t}$ & 0.039 & 0.022 & $<0.001$ & 0.216 & 0.186 & $<0.001$ \\
\hline$M A G E_{i j c t}$ & -0.087 & -0.062 & $<0.001$ & -0.215 & -0.192 & $<0.001$ \\
\hline$M F R E Q_{i j c t}$ & 0.103 & 0.069 & $<0.001$ & 0.000 & 0.000 & $<0.001$ \\
\hline$M F E X P_{i j c t}$ & 0.440 & 0.473 & $<0.001$ & 0.227 & 0.263 & $<0.001$ \\
\hline$M G E X P_{i t}$ & 0.141 & 0.149 & $<0.001$ & 0.076 & 0.081 & $<0.001$ \\
\hline DTOP10 & 0.662 & 0.583 & $<0.001$ & 1.000 & 1.000 & $<0.001$ \\
\hline$M N C O S_{i t}$ & -0.004 & 0.043 & $<0.001$ & -0.065 & -0.052 & $<0.001$ \\
\hline$M N S I C 2_{i t}$ & -0.019 & 0.030 & $<0.001$ & -0.091 & -0.088 & $<0.001$ \\
\hline$N$ & 178,455 & 376,559 & & 178,455 & 376,559 & \\
\hline
\end{tabular}

Variables are defined in Appendix. 
Table 3: Regression results of Model (1) for test of H1a and H1b: Based on pooled sample

$M A F E_{i j c t}=\alpha+\beta_{l} C F F_{i j c t}+\beta_{2} L M A F E_{i j c t}+\beta_{3} M A G E_{i j c t}+\beta_{4} M F R E Q_{i j c t}+\beta_{5} M F E X P_{i j c t}+$ $\beta_{6} M G E X P_{i t}+\beta_{7} D_{T O P 10}+\beta_{8} M_{i t} C O S_{i t}+\beta_{9} M N S I C 2_{i t}+\sum_{c}$ Country $_{c}+\sum_{t}$ Year $_{t}+\varepsilon_{i j c t}$

\begin{tabular}{|c|c|c|c|c|}
\hline & Predicted sign & Coefficient & t-value & p-value \\
\hline Intercept & & -0.0112 & -0.33 & 0.7398 \\
\hline$C F F_{i j c t}$ & + & 0.0099 & 2.93 & 0.0034 \\
\hline$L M A F E_{i j c t}$ & + & 0.1157 & 21.85 & 0.0000 \\
\hline$M A G E_{i j c t}$ & - & -0.2554 & -18.93 & 0.0000 \\
\hline$M F R Q_{i j c t}$ & + & 0.0584 & 7.43 & 0.0000 \\
\hline$M F E X P_{i j c t}$ & + & 0.0029 & 1.97 & 0.0489 \\
\hline$M G E X P_{i t}$ & + & 0.0015 & 0.58 & 0.5620 \\
\hline DTOP10 & + & 0.0120 & 3.43 & 0.0006 \\
\hline$M_{N C O S}$ & - & 0.0150 & 3.52 & 0.0004 \\
\hline$M N S I C 2_{i t}$ & - & -0.0146 & -3.22 & 0.0013 \\
\hline Country fixed effect & \multicolumn{4}{|c|}{ Yes } \\
\hline Year fixed effect & \multicolumn{4}{|c|}{ Yes } \\
\hline Adjusted $\mathrm{R}^{2}$ & \multicolumn{4}{|c|}{$7.62 \%$} \\
\hline No. of observations & \multicolumn{4}{|c|}{555,014} \\
\hline
\end{tabular}

Variables are defined in Appendix. 
Table 4: Regression results of Model (2): Test of $\mathrm{H2}$

$M_{A F E_{i j c t}}=\alpha+\beta_{1} C_{F F} F_{i j c t}+\beta_{2} C F F_{i j c t} \times$ CountryVariable $_{c}+\beta_{3} L_{M A F E_{i j c t}}+\beta_{4} M A G E_{i j c t}+\beta_{5} M F R E Q_{i j c t}+$

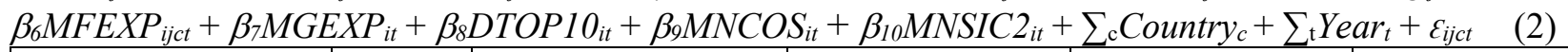

\begin{tabular}{|c|c|c|c|c|c|}
\hline & $\begin{array}{l}\text { Pred. } \\
\text { sign }\end{array}$ & $\begin{array}{c}\text { CountryVariable }= \\
\text { ANTI_DIR }\end{array}$ & $\begin{array}{l}\text { CountryVariable } \\
\quad=L E G A L\end{array}$ & $\begin{array}{l}\text { CountryVariable } \\
=\text { ENFORCE }\end{array}$ & $\begin{array}{c}\text { CountryVariable } \\
=\text { DISC }\end{array}$ \\
\hline Intercept & $?$ & $\begin{array}{c}-0.0354 \\
(-1.54)\end{array}$ & $\begin{array}{c}-0.0452 * * * \\
(-3.85)\end{array}$ & $\begin{array}{c}-0.0269 \\
(-0.00)\end{array}$ & $\begin{array}{c}-0.1649^{*} \\
(1.76)\end{array}$ \\
\hline$C F F_{i j c t}$ & + & $\begin{array}{l}0.0095 \\
(1.03)\end{array}$ & $\begin{array}{c}0.0072 * \\
(1.70)\end{array}$ & $\begin{array}{l}0.0269 \\
(1.45)\end{array}$ & $\begin{array}{c}0.0754 \\
(2.02)\end{array}$ \\
\hline CountryVariable $_{c}$ & + & $\begin{array}{l}0.0090 \\
(1.64)\end{array}$ & $\begin{array}{c}0.0544 * * * \\
(3.75)\end{array}$ & $\begin{array}{c}0.0054 \\
(0.00)\end{array}$ & $\begin{array}{c}0.0022 * \\
(1.75)\end{array}$ \\
\hline $\begin{array}{l}\text { CFF }{ }_{i j c t} \\
\times \text { CountryVariable }_{c}\end{array}$ & - & $\begin{array}{c}-0.0006 \\
(-0.25)\end{array}$ & $\begin{array}{c}\mathbf{0 . 0 0 0 5} \\
(\mathbf{0 . 0 7}) \\
\end{array}$ & $\begin{array}{c}-0.0023 \\
(-1.02)\end{array}$ & $\begin{array}{c}-0.0009^{*} \\
(-1.81)\end{array}$ \\
\hline$L M A F E_{i j c t}$ & + & $\begin{array}{c}0.1203 * * * \\
(20.87)\end{array}$ & $\begin{array}{c}0.1203 * * * \\
(20.87)\end{array}$ & $\begin{array}{c}0.1203 * * * \\
(20.87)\end{array}$ & $\begin{array}{c}0.1203 * * * \\
(20.88)\end{array}$ \\
\hline$M A G E_{i j c t}$ & - & $\begin{array}{c}-0.2435 * * * \\
(-17.51)\end{array}$ & $\begin{array}{c}-0.2435 * * * \\
(-17.51)\end{array}$ & $\begin{array}{c}-0.2435 * * * \\
(-17.51)\end{array}$ & $\begin{array}{c}-0.2435 * * * \\
(-17.51)\end{array}$ \\
\hline$M F R E Q_{i j c t}$ & + & $\begin{array}{c}0.0546^{* * * *} \\
(6.61)\end{array}$ & $\begin{array}{c}0.0546^{* * * *} \\
(6.61)\end{array}$ & $\begin{array}{c}0.0546^{* * * *} \\
(6.62)\end{array}$ & $\begin{array}{c}0.0546^{* * * *} \\
(6.62)\end{array}$ \\
\hline$M F E X P_{i j c t}$ & + & $\begin{array}{c}0.0034 * * * \\
(2.16)\end{array}$ & $\begin{array}{c}0.0034 * * * \\
(2.16)\end{array}$ & $\begin{array}{c}0.0034 * * * \\
(2.16)\end{array}$ & $\begin{array}{c}0.0034 * * * \\
(2.16)\end{array}$ \\
\hline$M G E X P_{i t}$ & + & $\begin{array}{c}0.0030 \\
(1.04)\end{array}$ & $\begin{array}{l}0.0030 \\
(1.05)\end{array}$ & $\begin{array}{c}0.0030 \\
(1.04)\end{array}$ & $\begin{array}{c}0.0030 \\
(1.04)\end{array}$ \\
\hline DTOP10 & + & $\begin{array}{c}0.0112 * * * \\
(3.00)\end{array}$ & $\begin{array}{c}0.0112 * * * \\
(3.00)\end{array}$ & $\begin{array}{c}0.0111 * * * \\
(2.97)\end{array}$ & $\begin{array}{c}0.0111^{* * *} \\
(2.96)\end{array}$ \\
\hline$M_{N C O S_{i t}}$ & - & $\begin{array}{c}0.0163 * * * \\
(3.72)\end{array}$ & $\begin{array}{c}0.0163 * * * \\
(3.72)\end{array}$ & $\begin{array}{c}0.0163 * * * \\
(3.71)\end{array}$ & $\begin{array}{c}0.0163 * * * \\
(3.72)\end{array}$ \\
\hline MNSIC2 $_{i t}$ & - & $\begin{array}{c}-0.0158 * * * \\
(-3.26) \\
\end{array}$ & $\begin{array}{c}-0.0158 * * * \\
(-3.26) \\
\end{array}$ & $\begin{array}{c}-0.0158 * * * \\
(-3.26) \\
\end{array}$ & $\begin{array}{c}-0.0158 * * * \\
(-3.26) \\
\end{array}$ \\
\hline $\begin{array}{l}\text { Country fixed } \\
\text { effect }\end{array}$ & & Yes & Yes & Yes & Yes \\
\hline Year fixed effect & & Yes & Yes & Yes & Yes \\
\hline Adjusted $\mathrm{R}^{2}$ & & $7.22 \%$ & $7.22 \%$ & $7.22 \%$ & $7.22 \%$ \\
\hline $\begin{array}{l}\text { No. of } \\
\text { observations }\end{array}$ & & 493,399 & 493,399 & 493,399 & 493,399 \\
\hline
\end{tabular}

Variables are defined in Appendix. t-values are provided in the parentheses. ${ }^{*}, * * * * *$ indicate significance level of $10 \%, 5 \%$, and $1 \%$, respectively. 
Table 5: Regression results of Model (5) for test of $\mathrm{H3}$

$M A F E_{i j c t}=\alpha+\beta_{l} C F F_{i j c t}+\beta_{2} I F R S_{c, t}+\beta_{3} C F F_{i j c t} \times I F R S_{c, t}+\beta_{4} L M A F E_{i j c t}+\beta_{5} M A G E_{i j c t}+\beta_{6} M F R E Q_{i j c t}+$

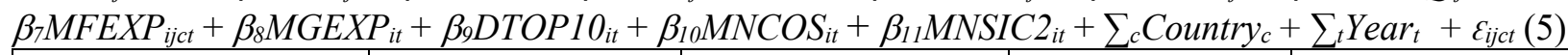

\begin{tabular}{|c|c|c|c|c|}
\hline & Predicted sign & Coefficient & t-value & p-value \\
\hline Intercept & $?$ & -0.0119 & -0.35 & 0.7260 \\
\hline$C F F_{i j c t}$ & + & 0.0258 & 6.60 & 0.0000 \\
\hline$I F R S_{c, t}$ & + & 0.0008 & 0.13 & 0.8976 \\
\hline$C F F_{i j c t} \times I F R S_{c, t}$ & - & -0.0359 & -5.46 & 0.0000 \\
\hline$L M A F E_{i j c t}$ & + & 0.1157 & 21.87 & 0.0000 \\
\hline$M A G E_{i j c t}$ & - & -0.2556 & -18.93 & 0.0000 \\
\hline$M F R E Q_{i j c t}$ & + & 0.0583 & 7.41 & 0.0000 \\
\hline$M F E X P_{i j c t}$ & + & 0.0029 & 2.00 & 0.0455 \\
\hline$M G E X P_{i t}$ & + & 0.0015 & 0.59 & 0.5572 \\
\hline DTOP10 $i t$ & + & 0.0121 & 3.47 & 0.0005 \\
\hline$M_{N C O S_{i t}}$ & - & 0.0150 & 3.53 & 0.0004 \\
\hline$M N S I C 2_{i t}$ & - & -0.0145 & -3.21 & 0.0013 \\
\hline Country fixed effect & & \multicolumn{3}{|c|}{ Yes } \\
\hline Year fixed effect & & \multicolumn{3}{|c|}{ Yes } \\
\hline Adjusted $\mathrm{R}^{2}$ & & \multicolumn{3}{|c|}{$7.63 \%$} \\
\hline No. of observations & & \multicolumn{3}{|c|}{555,014} \\
\hline
\end{tabular}

Variables are defined in Appendix. 